University of Louisville

ThinkIR: The University of Louisville's Institutional Repository

Electronic Theses and Dissertations

6-1964

\title{
The Board of Internal Improvement of Kentucky, 1835-1850.
}

Joe F. Decker

University of Louisville

Follow this and additional works at: https://ir.library.louisville.edu/etd

\section{Recommended Citation}

Decker, Joe F., "The Board of Internal Improvement of Kentucky, 1835-1850." (1964). Electronic Theses and Dissertations. Paper 325.

https://doi.org/10.18297/etd/325

This Master's Thesis is brought to you for free and open access by ThinkIR: The University of Louisville's Institutional Repository. It has been accepted for inclusion in Electronic Theses and Dissertations by an authorized administrator of ThinkIR: The University of Louisville's Institutional Repository. This title appears here courtesy of the author, who has retained all other copyrights. For more information, please contact thinkir@louisville.edu. 
THE BOARD OF INTERNAL IMPROVEMENT OF KENTUCKY, 11 $1835-1850$

\author{
A Dissertation \\ Submitted to the Faculty \\ of the Graduate School of the \\ University of Louisvilie \\ in Partial Fulfillment of the \\ Requirements for the Degree \\ of Master of Arts
}

Department of History

by

Joe F. Decker

11

June, 1964 


\section{Name of Student: Joe F, Decker}

Titlo of Thesis: THE BOARD OF IMTERNAL

IMPROVEMENT OF KENTUCKY,

$1835-1850$

Approved By Reading Committee Composed of the Following Members:

Name of Director:

Date: Jnul 5,1444 
CONTENTS

Page

ACKNOWLEDGEMENTS .............. iv

INTRODUCTION .................... I

I. THE NEED FOR INTERNAL IMPROVEMENTS . . . . . 3

II. SECTIONAL RIVALRY FOR STATE AID . . . . 10

III. THE CREATION OF THE BOARD OF INTERNAI

IMPROVEMENT ............. 20

IV. FURTHER LEGISLATION FOR INTERNAL IMPROVEMENTS. 33

V. THE MAJOR PROJECTS UNDERTAKEN . . . . . 39

VI. PROBLEMS IN FINANCING THE IMPROVEMENTS . . • 49

VII. THE END OF INTERNAL IMPROVEMENTS . . . . . 56

VIII. EVALUATION OF THE BOARD OF INTERNAL

IMPROVEMENT ..................... 62

APPENDIX . . . . . . . . . . . 73

BIBLIOGRA PHY . . . . . . . . . . 77 


\section{ACKNOWLEDGEMENTS}

Grateful acknowledgement is made to the staffs of The Filson Club, the Loulsville Free Public Library, and the University of Louisville Library, for their assistance in the research for this paper. Mr. Charles Hinds, Director of the Kentucky State Archives, was very helpful by allowing full use of materials found there. I am doeply Indebted to Dr. William Mallalieu and Dr. Leonard Curry for their evaluation and their suggestions which improved the paper greatly. 


\section{INTRODUCTION}

For a brief perlod of fifteen years, the Board of Internal Improvement occupiod a place of prominence in the political and economic affairs of Kentucky. From its creation in 1835, until the revision of the constitution In 1850 , the board spent vast sums of state money on the varlous projects for the internal improvement of the state. The magnitude of the undertaking, and the amount of state money spent, make this one of the most important areas for study in the political and economic development of Kentucky. The improvements which were made in the transportation facliltios of the state, and their cost to the state were subjects of controversy and discussion for many years. Through expenditures for these improvements, the state acquired a debt of considerable proportions. This debt, and the state's difficulty in making payments for its retirement, was one of the major items of debate in the Constitutional Convention of 1849-1850.

Thls study attempts to analyze the factors leading to the creation of the Board of Internal Improvement, the major projects which it undertook, and the decline of the internal improvement movement in Kentucky. The a im of this study is to evaluate the success of the Board of Internal 
Improvements in its supervision of the state ald for internal improvements. This evaluation includes an effort to determine the worth of the projects to the economic development of the state, and their value when considered as state investments. 


\section{CHAPTER I}

\section{THE NEED FOR INTERNAL IMPROVEMENTS}

The need for adequate facilitios for transportation and communication was recognized at an early date by the settlers of Kentucky. The first attempts at providing for this neod were made by the General Assembly of Virginia. Acts were passed for the improvement of the mountain roads soon after the first permanent settlements were made in central Kentucky.

The Virginia laws generally provided for the appointment of commissioners who were empowered to collect subscriptions, let out the roads to undertakers, and supervise the Improvements. 1 Persons owing delinquent taxes could make payments to the road fund and satisfy their debts. Th1s allowed persons to pay their taxes and benefit from having roads near their homes improved. The work was done by local residents, who were required to work on the roads a prescribed amount of time. The state did make some contributions in the form of land grants, and in some cases, appropriations were made from the public treasury. ${ }^{2}$

IVirginia, Statutes At Large (Henig, Vol. X, 1822), Chapter XII.

2Ib1d. (Vol. XII, 1823), Chapters XII, LXXV. 
Th1s mothod of road improvement and maintenence was continued by the state of Kentucky after 1ts separation from Virginia. Acts were passed by the legislature appointing cormissioners and setting their specific duties. The main improvements consisted of the remoral of obstacles which made passage over the so-called roads impossible.

During this perlod, there was also some work done on the major streams in an effort to improve navigation. Hero too, only the obvious snags and obstacles were removed, and river traffic depended on the amount of water and the ingenuity of the boatmen. Even though passage on the streams and rivers was somewhat hazardous at best, Kentucky was considered fortunate to have so much navigable water. Like most of the other southern states, Kentucky relled heavily on these streams and neglected to bulld roads as quickly as the need for them dereloped.

The General Assembly approved the charters for the Lexington and Loulsville Turnpike Road Company, and the Lexington and Maysville Turnpike Road Company, in 1817.3 However, there was no systematic provision for roads throughout the state, and awards of state ald continued to be made by the legislature for each individual project. The main state function was the chartering of private

3General Assembly of Kentucky, Acts of The General Assembly of Kentucky, 1817-18, (Frankfort: Kendall and Russe11, 1818), C. 113, sec. 1 . 
companies to construct turnpikes and collect tolls on the roads. Before 1835, the state of Kentucky had spent only $\$ 312,502$ for internal improvements. Of this amount, $\$ 279,002$ was spent for turnpike roads, and only $\$ 33,500$ for improvement of streams. 4 This expenditure is negligible when compared with that made by many of the other states. By 1822, the state of Pennsylvania had invested over $\$ 2,000,000$ on turnplkes alone. 5 In New England and the Middle Atlantic states, private investments provided financing for most of the turnpike roads. However, there was no great source of private capital in Kentucky, and an adequate program of internal improvements could only be achleved through state leadership in financing.

Jackson's veto of the Maysville Road Bill settled the question of Federal ald for internal improvements in the states. This removed the hope that desired projects could be undertaken without extensive use of state money, and caused more pressure to be brought upon the legislature for action.

The conditions of the roads and the difflculties of travel were frequently commented upon by travelers of the

4General Assembly of Kentucky, "Report of the Board of Internal Improvement for 1837," Journal of the House of Representatives 1837-38, (Frankfort: A. G. Hodges Pubilc Printers, 1838), Appendix, p. 405.

5 George Rogers Taylor, The Transportation Revolution, 1815-1860 (Vol. IV of The Economic History of the United States, ed. Henry David et al (9 vols.; New York: Rinehart and Company, 1951), p. 25. 
perlod. A traveler to Kentucky in 1825 made these observations on travel and internal improvements within the state:

The weather was now wet and the roads deep. The Legislature of Kentucky have as jet done but little on the subject of internal improvements. In wet weather, the traveling is deep, and sometimes the roads are almost impassible for whoel carriages. This is rendered worse from the circumstances, that throughout the thicker settlements of the state, the farms adjoining the highways are all onclosed by fences and the road, for miles together, is a continued lane. If it be difficult of passage in winter, these lanes render it equally uncomfortable to the traveller in the sumer, by his continued exposure to the unshaded beams of the sun. The necessity of good roads is so strongly felt by the people of the state, and those engaged in the commerce of the country, that they are calling on the logisfature to make an exortion for thelr improvement. 6

The small amount of progress which was made toward providing roads fit for travel can bost be 1llustrated by a comparison of this account with that of another traveler in 1837.

I rode alone from Groensburg. Fow persons here perform journeys in the stage. There is reason for 1t. The mass of voyagers are unable, or unwiling to pay the extravagant price demanded for the privilege of being jolted over the country in that rohicle. The fare is ten conts a mile-nearly double what it is in Marylandand this 18 not all. At the hotels and taverns, the stage passenger is obliged to pay fifty cents for the most ordinary meal. The price for tho other travellors is precisely half of that sum. 7

6Earl Gregg Swem (ed.), Ietters on the Condition of Kentucky in 1825 (New York: Charles F. Heartman, 1916), p. 68.

7Frederick Hall, Letters From the East and From the West (Washington: F. Tajlor and Wm. Morrison, 1840), p. 140. 
Finding that the stage did not go to the desired destination, the traveler was forced to proceed by wagon, and later on by horseback over a blazed trall. The following account of a wagon road polgnantly describes the lack of adequate transportation facilities to the smaller towns and communities.

The road was horrible-being recently made, not worked at all with the plow, filled with a million small trees, cut low down; that is, six or olght Inches above the surface, and over which it was quite impossible for the driver to prevent his wheols from passing. You have seon poople harrowing in grain, on now and rough land, whon the toothod instrument was, every instant, jerked hither and thither, never moving ahoad with a steady pace. So it was with our vehicle. I noed not teli you that in this ton mile jaunt, I have been thoroughly jolted and pommelled. 8

While the difficulties incurred proved a hardship to the occaslonal traveler, the lack of good roads and waterways constituted a severe detriment to the commerce of the state. If stagecoaches were barely able to make their way over the maddy, stump-11lled roads, there was greater difflculty driving heary wagons loaded with goods. Bulky commodities were usually transported by flat-boats, floatIng downstream in the spring when the river lovel was high. The rivers offered a good avenue for commerce when the conditions were right, but such was not always the case. The level of water in the rivers was subject to excoedingly wide and sudden fluctuations. Boats were often tied up for lack of water in the summer months and had to combat the

${ }^{8}$ Ib1a., p. 141. 
roaring floods of fall and spring. Extended perlods of low water made ledges of rock and sand bars a dreaded threat. To these menaces were added the greatest menace of all, the snags. Great trees were thrown into the water by constantIf crumbling banks and became caught in the river bed.

These presented the greatest hozard to navigation.?

In many areas, comerce and trade was practically nonexistent, because goods from the east could not be brought In and surplus cash crops could not got to market. Tho cost of transporting items from landings on the Ohio to areas within the state often exceeded thelr original cost in the clties where purchased.

A Unfted States englneer, reporting on a survey of the Cumberland River in 1835, commented upon the difficulty in transporting tobacco when the river was at low stage.

The raising of tobacco is now comparatively neglected from the difficulty of getting the crop to market. The counties of Wayne, Pulaski, and Whitley, formerly ralsed large quantities of this product, but, owing to the above cause, have abandoned its culture almost entirely. I was told, as low down as Burksville, that three-fourths of all the tobacco brought to that place for shipment the previous year still remained in the warehouse, the owners having boen unable to get it afloat before the waters foll so as to render it impossible to transport it to market. 10

Agitation for state ald in Improvement of transportation Increased rapidly after 1830. Although the leglslature

Taylor, The Transportation Revolution, p. 65 .

$10_{\text {General Assembly, "Report of The Board of Internal }}$ Improvement for $1835, "$ House Journal (1835-36), Append1x, p. 7 . 
issued charters to private companies at an increasing rate, there was st1ll no concentrated state effort to plan for a co-ordinated system of transportation which would utilize the fullest potential of the states' natural and financial resources. Laws piled up in each session of the legislature. However, little effective action was taken and the facilities for travel and transportation continued to be poor in most areas. Some short stretches of improved road were bullt by turnpike companies; the most important was the Louloville-Shelbyville road, part of a "great highway" crossing the state betweon Louisville and Maysville. But most of this route was a simple "dirt road" until state funds made improrement possible. 
CHAPTER II

SECTIONAL RIVAIRY FOR STATE AID

While it had become apparent that some type of effective state assistance for internal improvements should be made, there was little agreement on specific projects to be undertaken. The sentiment for internal improvements was tempered by the suspicion that work undertaken at state expense would benefit only a small segment of the state, perhaps to the detriment of trade in other areas. This suspicion was especially prevalent in Loulsville and LexIngton, where rivalry for trade was extremely keen. There was also a great deal of friction between adrocates of river improvement, centered in Frankfort and Bowling Greon, and the turnpike and rallroad factions, located in Louisville and Lexington. This was due to the location of the respective cities, and each was anxious to promote her own interests. Lexington and Louisvilie would gain little from improvements on Kentucky rivers, and might possibly suffer a loss of trade if they were made.

As mentioned in the previous chapter, the bulk of the state's expenditure for Internal improvements before 1835 had been for turnplke roads. Very little money had been spent on river improvement, and none on the construction 
of canals or rallroads. However, the river interest was gaining in political strongth, and was bocoming a force to be considered. This was effectively pointed out in an oditorial in the Frankfort Commonwealth, attacking the position taken by some of the Lexington writers. These writers, who were mainly interested in turnpikes and railroads whlch would benefit lexington, had charged the proposed river improvements with being beneficlal to a small section of the state only. The Commonwealth replied with a statement of the position of the supporters of river improvement.

The river interest embraces a majority of the counties in the State-Iicking, Big Sandy, Cumberland, and Green Rivers all dopend for their value upon the successful application of the same kind of improvements which are contemplated on the Kentucky. Some of the Lexington writers have already been so unfortunate as to give offence to the two leading papers in Loulsville, to the Westorn Citizen at Paris, to one, and perhaps both of the Maysville papers, and, if the river interest is ridiculod, the paper at Bowlinggreen will bo in a similar attitude. This will form a cordon of opposition possessing great political, if not water, power.l

Probably the leading exponent of state ald for river improvement, the Commonwoalth carried on a running debate with many newspapers throughout the state which held different views toward internal improvements. One of the most interesting exchanges occurred between the Commonwealth and the Iouisville Journal in September and October, 1834 .

IFrankfort Commonrealth, Fobruary 4, 1835. 
A series of articles appoared in the Journal, during these months, dealing with the neod for internal improvements. The articles, appearing with the name "Evans" given as author, stated the position of most of those in Loulsville who were desirous of increasing her conmercial Importance in the state of Kentucky and the Ohio valley.

"Bvans" saw the construction of canals and rallroads in the Middle Atlantic states as a threat to the Louisville business interests. These canals and the early rallroads, if successful, together with a network of turnpikes and railroads in the central and eastern regions of Kentucky, threatened to divert the trade of these regions away from Loulsville. 2

While the debate between Loulsville and Lexington centered around the type of improvements to be sponsored by the state, the greater rivalry existed betwoen Loulsville and Cincinnat1. The Lexington interests used this rivalry to their own advantage in attempts to secure state aid for the construction of rallroads and turnplkes which would maintain their position as the road hub of the state; at the same time, socuring for her a similar honor in railroad bullding.

During the yoars after 1830, Loxington had found herself in the position of slowly but surely giving way to the riparian towns. The merchants of Lexington had realized

2The Louisville Journal, reprinted in the Frankfort Commonwealth, September 27, 1834 . 
this and determined that something would have to be done to maintain the importance of the city as the center of cormerce of the wealthy Bluegrass region of the state. By 1830, the situation had developed further and Lexingtion found herself between two fires. Because of the extremely unfavorable topographical conditions, a canal could not be constructed, and the Jackson veto of the Maysville Road Bill temporarily killed her hopes for an improved highway system. 3

These factors forced Lexington to consider the possibility of constructing a rallroad in order to continue as the marketing conter for the Bluegrass. This very fertilo agricultural region could increase its productiveness only as fast as marketing faclilties could be provided. The proposal to connect Lexington and the Ohlo River stirred the Imagination of those who saw unlimited prosperity for this productive area.

The promoters of the railroad sought state aid in the financing of the project. The strongest argument in favor of the undertaking was that Kentucky had not already inrested large sums of money in canals which were likely to become useless, as had several of the other states. The argument was also advanced that the contral portion of the

3Thomas D. Clark, "The Lexington and Ohlo Rallroad-A Ploneer Venture," The Register of the Kentucky State H1storical socioty, v01. 31, No. 94 (January, 1933), p. 9. 
state was productive enough to support a rallroad. 4

The request for a charter for the Lexington and Ohio rallroad was opposed by a delegation from Loulsville, on the grounds that it did not specify Louisville as the western terminus of the road.5 The fear that cincinnati interests were attempting to divert the commerce of the woalthy contral region of the state was expressed in an article by "Evans". He felt the rallroad from Lexington would extend westward only as far as Frankfort, and another rallroad would bo built from Lexington to Covington, with the ald of the oltizens of Cincinnat1. 6 His proposals to combat such a scheme included bullding a turnpike or railroad from Loulsville to Nashville, and the linking of Louisville and Lexington by means of a railroad. 7 This would form an effective transportation net with Loulsville in the key position for trade. This would thwart cincinnati's efforts to gain a link with the south and establish her sphere of influence there.

Another phase of the rivalry between Louisville and Cincinnati developed over the charter for the Cincinnati and Charleston Rallroad. The proposal to link the two cltios with a rallroad by way of the French road and the

4IbId., p. 10.

In1d., p. 12.

6The Loulsville Journal, reprinted in the Frankfort Commonwealth, September 27, 1834 .

Trold. 
Cumberland Gap was greoted with wild jubllation. A charter for the road was granted by South Carolina in 1835, and the states of North Carolina, Tennesser, and Kentucky soon gave supporting action. 8 However, in return for a franchise to cross the state of Kentucky, the legislature demanded a brench line to Louisville. Thus, the line became known as the Loulsville, Cincinnat1, and Charleston Rallroad. This demand for the branch line, together with the difficulty of ralsing funds outside of South Carolina and the panic of 1837, defoated the overall project to connect Cincinnat1 with the Atlantic.9 Jamos Guthrie, a leading figure in the area of internal improvements in Kentucky is said to be responsible for the fallure of this undertaking. "Guthrie was unwilling to have any further prestige go to a rival of Louisville, and he influenced the general assembly to substitute the names of Loulsville, Covington, and Maysville in the charter." 10

This rivalry between Louisvilie and Cincinnati, with the southern markets as the prize, was characteristic of the struggle which oxistod botwoen many citles during the

8Carter Goodrich, Government Promotion of American Canals and Railroads, $1800-1890$ (Now York: Columb1a University Press, 1960), p. 104.

9Charles H. Ambler, A Hiatory of Transportation in the Ohio Valler (Glendale, California: The Arthur H. Clark Company, 1932), p. 232.

10Robert S. Cotterill, "James Guthrie-Kentuckian, 1792-1869," The Register of the Kentucky State Historlcal Soclety, Vol. 20, 10. 60 (September, 1922), p. 291. 
perlod. Pittsburg and Wheoling were rivals in much the same way, and continued to be for many yoars. In the beginning, Cincinnati had the advantage and plajed the major role. However, Loulsville had many natural advantages, and relled upon her location at the Falls of the Oh10, a natural gateway to the south, to make her the leading commercial center of the interior. 11

Loulsville therefore looked with favor upon the possibility of substantial state financial support for internal improvements. The prospects for the continuation of the rallroad from Frankfort to Loulsville looked good, particularly if state ald could be obtained. This, together with the apparent fallure of the Loulsville, Cincinnati, and Charleston Rallroad, had blocked efforts of Cincinnati interests to reach the markets of the south by means of a rallroad.

During these years of conflict between the two cities for location of proposed rallroads, the river interest in Kentucky had not beon silent. From 1830, agitation had increased for improvement of the state's natural waterways to provide for year-round navigation. Primary attention was given the Kentucky River, for it was felt that other profects would be undertaken if enough support could be obtained for this river system. The Commonwealth, in 1ts

\footnotetext{
11Ambler, A History of Transportation in the Ohio Valley, p. 231 .
} 
campaign for a state program for internal improvements with major emphasis on river development, called for action by the logislature.

A good highway is now complete from Iexington to Loulsville, and the question is, is it not high time that the attention of the Leglslature should be directed to the improvement of the Kentucky River, and thus establishing another channel of communication with the Ohio, which will penetrate into the very heart of the State-develop the resources of an extensive region of country, which without such an improvement, must be forever valueless-open up a way to the inexhaustible coal mines near the sources of the Kentucky, and also to the salt works which are in the same rogion, whilo a trade in lumber would at once be actively commenced. 12

The article also called for an examination of the possibility of joining the Kentucky and Cumberland rivers through a system of canals. Even though Kentucky had mado Iittle contribution to the improvement of its facilities for transportation to this time, the people of the state had many Imaginative schemes whlch they proposed.

In spite of the disagreement over the type of improvements to be made, there was general agreement that it was time that the state made some investment in works of public improvement. In comparison with other states, Kentucky's contribution was negligible before 1835. The abundance of streams and rivers had caused men of limited vision to rely on natural avenues of commerce which were at best unpredictable, and at their worst, impossible. The c1tizens of

12Frankfort Commonwealth, September 27, 1834 . 
Lexington showed rare imagination and sound judgement in their early desire to construct a rallroad. The need to relleve their landlocked location and maintain their commerclal importance to the central region of the state, required strong, positive action.

Rallroads, which possibly furnished the answer to Kontucky's transportation problems, were in a primitive stage of development. The state was uninterested in their development at this time, but would later be forced to take over control of the Lexington and Frankfort Ra1lroad when severe financial difficulties forced construction to be halted. The costs of construction were high and the railroad was handicapped by poor quality of equipment. Despite these advantages, the rallroads did offer a possibility for investment. However, there was no railroad interest to compare with that of rivers and turnpike roads. The state ald for rallroads would nevor amount to much, and would be confined primarliy to the Lexington and Oh10. The great bullding booms of the $1850^{\prime}$ s and $1860^{\prime} \mathrm{s}$ would rely on local governments in the state for financial asaistanco. By the fall of 1834, conditions were right for the boginning of a state pollcy of substantial ald for internal improvements. Advocates argued that the state would have no difficulty in borrowing the necessary money to finance the projects, and that the tolls collected would be more than sufficient to rotire the debt. 
It was generally accepted that all soctions of the state would benefit to some extent from the improvements. While all areas might not benerit to the same degreo, each was wiling to go along with the scheme in the hopes of recelving some small portion of the money to be spent.

The legislature met in Frankfort in December, 1834 , ready to initiate a program of state aid for internal improvements. They were convinced that the present method of providing for the transportation needs of the state was inadequate, and a more positive approach was necessary, which could co-ordinate the various projects to provide the greatest possible benefit to the state needed to be estab11shod.

Considering the many sectional and local groups who were promoting their own interests, it should have been apparent that any great financial involvement by the state in internal improvements was bound to end in controversy. 
CHAPTER III

THE CREATION OF THE BOARD OF INTERNAL IMPROVEMENT

Sentiment for a massive program of state ald for intornal improvements had roachod its poak, and the time for enactment of legislation to achleve this aim was near. The debates and discussions over the type of internal improvements to be made had stimulated interest in the subject and had served a useful function. Attention had boen focused on the need for an Improved system of public transportation.

The General Assembly of Kentucky finally turned to the task of providing for the improvement of existing facilIties, and the creation of new and better ones. After some debate, a bill was passed to provide for the creation of The Board of Internal Improvement. The representatives from counties bordering on the major streams and between the major citles wore almost unanimous in their support for the bill.

The chlef opposition to the bill came from those areas which expected to gain the least amounts of state a 1d. The most solid opposition was from the region south of the Groen River and east of the Cumberland. Other concentrations of opposition were in the counties between the Licking 
and Kentuciry Rivers, the counties bordering the Tennessee River on the east, and the area containing the counties of Meade, Hancock, Brockinridge and Grayson counties. 1 The representatives from some countios split in their vote, but most sections were elther for or against the bill, depending on the possible amount of money to be recelved. The b11l passed the House of Representatives by a vote of 58 to 40.2

This lengthy bill made provision for the creation of a board to administer the state funds appropriated for the purposes of internal improvement. The board was to consist of four members, with the governor serving as ex officlo member and president of the board. He was to appoint the other members, subject to the approval of the Senate. The board was to be appolnted on an annual basis, and the governor was given the authority to fill any vacancy which might occur. 3

The board was authorized to employ one principal engineer at a salary not exceoding two thousand dollars annually. 4 This englneer was to bo instructed to make a survey of all the navigable streams of the state, together

$l_{\text {General Assembly, House Journal }}(1834-35)$, p. 325. The Journal of the Senate for 1834-35 is not arailablo 1008 IIJ.

2 Ibld.

3General Assembly, Acts of the General Assembly (1834$35)$, c. 837 , sec. 1 . 4Ib1d., sec. 2 . 
with a survey of all the public turnplke roads, for which the legislature might have had chartered companies. 5 The report of this engineer was to be presented to the legislature with an estimate of the cost, practicability, and public utility of the proposed work.

The board was authorized to subscribe for stock in chartered turnpike road companies in amounts oqual to that subscribed by individual stockholders. The wording of this provision was to become one of the factors in the controversy over the involvement of the state in undesirable turnpike projects. The act apparently gave the board I1ttle discretion in the application of state funds to turnpike roads:

That the said Board of Internal Improvement bo, and they are hereby authorized, on behalf of this commonwealth, to subscribe for stock in any incorporated company now existing (and in which the capital stock is not wholly taken up), for the purpose of constructIng any turnpike road in this commonwealth, an amount not excoeding the amount of stock subscribed by individual stockholders; and in like mannor, sald board are authorized to subscribe, on behalf of the commonwealth, in all chartered turnpike companies hereafter created, stock to an amount equal to the subscription of Individuals in said company: Provided, that in all companies heretofore created, in which the commonwealth has already taken stock, such stock shall bo considered as part of the stock hereby authorized to be taken; and the said board shall, only, in such cases, be authorized to take such additional stock as shall make the interest of the state equal to that of the Individual stockholders. 6

This provision was modifled somewhat by a later

5 Ib1d., sec. 3 .

6Ibld., sec. 4 . 
section of the bill which allowed the board to subscribe for stock on a two for ono basis in certain instances. In counties where sufficient individual subscriptions could not be obtained, the board could exercise their fudgement in the awarding of this additional state subscription. 7

The state's subscription for stock in turnp1ke road companies was to be made on an equal basis for the threo main sections of the state. These sections were to consist of the lands on the north side of the Kentucky River, between the Green and Kentucky rivers, and south of the Green River. 8 It was later made mandatory that a member of the board be appointed from each of these areas of the state to insure equal distribution of public funds.

The possibility that state funds might not be called for in one of these areas was forseen, and provision was made for their distribution to other areas of the state in the event this occurred.

That if the sa1d Board of Internal Improvement should not be called on, according to the provisions of this act, to subscribe the full amount authorized to be borrowed under this act for making tumpike roads, within one year, then, and in that event, the aforesaid Board of Internal Improvement, may subscribe the sum which may remain un-subscribed, in turnpike roads in any part of this commonwealth, where individuals or corporate bodles may have subscribed and paid in the like amount which the sald Board of Internal Improvement may be required to subscribe.9

7Ib1d., sec. 25.

8Ib1d., sec. 14 .

9 Ibid. 
In order to meet the subscription for stock in these projects, the governor was authorized to issue and sell bonds or scrip of the state in the amount of one million dollars. These were to bear interest at a rate not exceedIng five per cont, and were to be redeomable after twenty yoars and within thirty years.10 Only $\$ 422,000$ in bonds were sold during the year 1835.11

The act which provided for the creation of the Board of Internal Improvement actually represented a compromise between those favoring turnpike roads and those who desired to improve the rivers. Each type of improvements would receive a portion of the money to be spent. The passage of the act thus satisfied most of the advocates of internal improvements.

Spocific appropriations were made for most of the Important rivers and streams throughout the state. A survey of these stroams was to be made and plans for their improvement, together with an estimate of the cost, were to be submitted to the Board of Internal Improvement. If the board approved the plans, they were then to be submitted to the legislature for approval before the appropriated funds could actually be spent.

Specific appropriations were made for improvement of

10Ib1d., sec. 5 .

1IGeneral Assembly, "Report of the Commissioners of the Sinking Fund for 1850," Leglslative Documents, 1850-51, (Frankfort: A. G. Hodges and Company, 1851), p. 557. 
the major streams of the state. These appropriations were as follows:

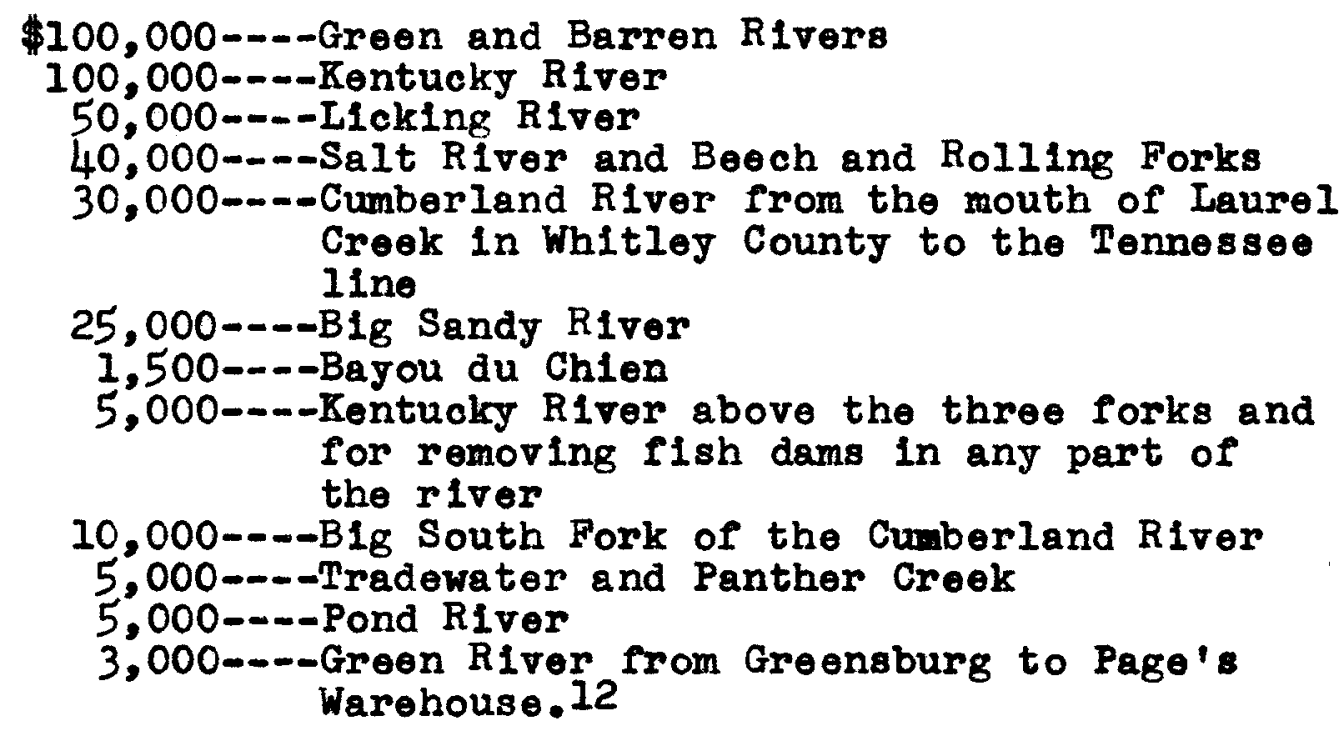

The survey of the Cumberland River by the United States Engineor was to be accepted by the board if it proved feasible. If not, the state engineer would then be required to make a survey in compliance with the act.

The act which created the Board of Internal Improvement falled to adequately describe the specific duties of the board. The terms under which state funds were to be Invested in turnpikes were established by the leglslature, the amounts to be spent on each individual stream or river was stipulated by the act, and the money appropriated for river improvement could not be used for turnpikes unless the leglelature refused to approve the survey and plans for Improvement of the stream. Even then, the money could not

12General Assembly, Acts of the General Assembly $1834-35$, c. 837 , soc. 6 . 
be otherwise spent unless the legislature so directed. 13

The tolls and profits from the stock of the state in turnpike companies were to be used for the retirement of the bonds at maturity. The governor was to report to the auditor the amount of bonds and scrip sold, and to include this in his report to the legislature. The board was required to make a report of Its activities to the legislature annually. Money for expenses incurred in making the necessary surveys was to be obtained by drawing upon the state auditor.

This act also created local boards of internal improvement in Calloway, Graves, Hickman, and McCracken counties In the western section of the state. The lands in these counties which were considered vacant lands were to be sold and the proceeds were to be used by the respective counties for the purpose of internal improvement. The local boards were given full power to select the objects for improvement, giving first consideretion to bullding bridges on the most important roads, and the cross-swaying of the bottoms and swamps on the most important public roads. Tho clearing of the obstructions to navigation on the navigable streams of their respective counties was also within their authority. 14 While there were to be other local boards of internal improvement through which the Board of Internal Improvement

13 Ibid., sec. 13.

14 Ibld., sec. 16 . 
was to administer state funds, the boards in these designated counties were in somewhat of a farored position. These arrangements were apparently mado in order to gain support from this section of the state for the passage of the act. The representatives of those counties were unanImous in their support of the act in the House of Representatives. This takes on added significance when viewed in light of the Congressional elections of 1837. The Whigs, who were committed to a program of internal improvements, elected their candidates in every district of the state except the first district which included these western counties. There they had no candidate who made a significant showing. 15 Yet, the section furnished strong support for the passage of this act, which would later be blamed on the Whigs. 16 The support for internal improvements was based on the amount of state money which could be drawn to a particular portion of the state, rather than upon party views or soclal philosophy.

In the debates concerning the state debt at the convention for the revision of the constitution, James Guthrie of Louisville discussed this aspect of internal improvoments.

Though there are a great many others who voted against 1t, st111, whenever they could draw any

15The Whig Almanac for 1843 (New York: Greeley and McElrath, 1843), p. 39.

16General Assembly, House Journal $(1834-35)$, p. 325 . 
little bonus to their section of the state, they always accepted 1t. Why, the lands west of the Tennessee River were given up to that section of the country, to bo expended for internal improvements; and the statutes show that they received and used them. To the mountain region we gave but little; but we gave them the unapproprlated public domain; and they received and used it. A pitiful gift it certainly was, yet they took 1 . 17

The creation of the board was greeted with wild acclaim by proponents of state financing of internal improvements. The Frankfort Commonwealth had high hopes for the future of the state as it reported on the firgt meeting of the board.

Who can predict the aspect Kentucky will prosent when her streams become permanently navigable and when all her roads through the interior become commodious channels of trade? The day is fast approaching when the difficulties of transportation and travel which have been encountered by this community, will live in tradition only and be Ilstened to with incredulity by the rising generation. We have begun the good rork, it is true, at a late date, but this consideration should only stimulate us to greater efforts in order to enable us to overtake those states who have got so many years the start of us. 18

The first activity of the board was the hiring of a principal engineor and an assistant engineer, to begin the work of surveying the proposed projects as directed by the legislature. After some delay in selecting the engineer which the board felt to be best qualified, Major R. P. Baker was appointed principal engineer in August, 1835.

17Roport of the Debates and Proceodings of the Convention for the Revision of the Constitution of the State of Kentucky, 1849, (Frankfort: A. G. Hodges and Co., 1849), p. 771. Hereafter referred to as Convention Dobates.

18 Frankfort Commonwealth, March 21, 1835. 
N. B. Buford was named as assistant engineer to ald him in making the required surveys.

About September 20, 1835, the two engineers began a joint survey of the Kentucky River to determine its adaptability for slackwater navigation. The survey was made to ascertain the practicablilty of converting the river into an artificial canal useful for navigation the jear round. 19 The engineers reported favorably on both aspects of the Improvement, and gave lengthy estimates as to the amount of trade which would pass over the river if the contemplated improvements were made.

Favorable reports were also given on the foasibility of Improving the Green and Licking rivers after surveys had been made on these streams. The survey by the United States Eng ineer of the Cumberland River was regarded as favorable and was accepted by the board. In all of these reports on surveys made, the engineers stressed the value of the Improvements to the commerce of the area reached by the streams.

It was anticipated that vast amounts of Kontucky products could be substituted for those products currently being brought in from outside the state. The engineers estimated that the amounts of coal, salt, and lumber being shipped in from the East could be replaced by using

19General Assembly, "Report of the Board of Internal Improvement for 1835," House Journal (1835-36), Append1x, p. 2 . 
existing Kentucky supplies. 20

The judgement of the engineers as to the practicability of improving the streams was to prove sound. While recommending the improvement of these four rivers, they felt that it was not advisable to construct a system of locks and dams on the Big Sandy, and the Rockcastle rivers at this time. They adrised that some deopening and widening of their channels would be sufficient for the time being. 21

While it is ovident that the ongineers wore well qualifled as to their knowledge of construction and location of Improvements to be made, they seem to be somewhat mistaken as to their estimates of the cost of these projects. Actual costs of construction were to run from three to five times the estimates made by the engineers. 22 This can not be wholly blamed upon the judgement of the engineers, for construction costs were undoubtedly made exorbitantly high by unscrupulous contractors who were anxlous to take advantage of the opportunity for large profits at the expense of the taxpayers.

The engineers cannot be criticlzed for boing narrowminded for their report endorsed one of the wildest schemes which could have beon proposed. The plan was to link Kentucky with the Atlantle Ocean, using a series of canals and

20 Ib1d., p. 6 .

21Ibid., pp. 46-60.

22General Assembly, "Report of the Board of Internal Improvement for 1842," Leglslative Documents $(1842-43)$, p. 60. 
tunnels to join the streams and rivers between the Cumberland and the Savannah rivers. Major Baker called the scheme highly possible. "I could not avold regarding the route as presenting highly ellgible facilitios for the construction of a channel of the most important character between the Ohio and the Atlantic; and that Kentucky could thus be made the most conspicious link in the chain." 23

However, Baker, who was regarded one of the most competent enginoers of his time, was obviously wrong in his estimation of the cost of such a project.

It will, upon reforence to the accompanying est1mate, be seen, that the average cost per mile of a lock and dam narigation, upon the most perfect plan will but 11ttlo, if any, exceed one-half that of a turnpike road.... The most perfect kind of canal can be constructed for one-half the cost of the most perfect rallroad. The experience of the northeastern states bas fully settled the question, that the cost of transportation of rallroads exceod that upon canals by two or threo hundred per cent. 24

With this type of advice and leadership by the technical experts, the board began actual construction projects which would cost several times the amounts originally anticipated. The signiflcance of the inaugaration of an organized system of state financial ald for internal improvements cannot be overlooked by the serlous student of economic history. Throughout the next fow years, this program would overshadow all other programs of the state government. The money spent would rise to amounts never dreamed of by the

$$
\begin{aligned}
& 23 \text { Ib1d., p. } 17 . \\
& 24 \text { Ib1d., p. } 18 .
\end{aligned}
$$


adrocates or opponents of the movement.

The act which created the Board of Internal Improvement was far from perfect and the members of the legislature were quick in their efforts to provide further legislation. In fact, this would occupy a place of prominence in the affairs of the legislature during the next several years. 
FURTHER IEGISTATION FOR INTERNAL IMPROVEMENTS

The legislature considered the act of 1835 an important step toward the achievement of an adequate system of transportation in the state. However, it was quick to realize that more specific provisions were needed. One of the most important needs was the definition of the powers and duties of the Board of Internal Improvement.

The passage of an act in 1836 partially spelled out the duties of the board. The act provided "that the general care and superintendence and control of all the public improvements for interior communication in this state, whlch shall belong in whole or in part to the Commonwealth, shall, to the amount of such interest be rested in the Board of Internal Improvement." 1

The act seems to imply that the board would have considerable freedom of action, but the legislature retained firm control over the board. It continued to specify projects to be undertaken, and made appropriations for these projects. It also gave the conditions under which the appropriations could be spent.

laneral Assembly, Acts of the General Assembly (183536), c. 373, sec. 1 . 
The membership of the board was changed, and the govornor was no longer to be president. The president of the board was to be appointed by the governor and approved by the senate. The three members of the board were to be appointed, with one coming from each of the three main areas of the state as outlined in the original act. ${ }^{2}$ The section of the act which had allowed the board to subscribe for stock in turnpike roads anywhere within the state if funds were not called for in one of the three sections, was repealed. It was made unlawful to subscribe more than onethird of the amount authorized in any one section of the state. 3

The governor was authorlzed to issue scrip or bonds in an amount not to exceed one million dollars. This was to be in addition to the amount authorized in 1835.4 The amounts which had been stipulated for the improvement of the varlous rivers and streams were to remain the same unloss specifically changed. The residue from the sale of the bonds was to go for the construction of turnpike roads according to the regulations for the state subscription for stock. The scrip and bonds were to be redeemable in thirty and thirty-five yoar periods. Any unsold bonds from the 1ssue of the previous year were to be redeemable within

$$
\begin{aligned}
& 2 \text { Ib1d., sec. } 3 . \\
& 3 \text { Ibld., c. } 113, \text { sec. } 3 . \\
& 4 \text { Ib1d., c. } 373, \text { sec. } 16 .
\end{aligned}
$$


within these periods also. 5

The board was also authorized to subscribe for stock In the Lexington and Ohio, and the Green River railroads, in the amounts of $\$ 200,000$ and $\$ 150,000$, provided 11ke amounts should be subscribed by individuals. 6

In order to insure the payment of interest on the money borrowed for the purposes of internal improvement, and to provide for the final redemption of the loans, the legislature established a sinking fund. This fund was to be made up of the tax on the capital stock in the Bank of Kentucky, the Northern bank of Kentucky, and the Kentucky Bank of Loulsvillo. Also, the excess of the state dividends on her stocks in those banks, after paying the interest on the state bonds sold to pay for the stock, was to go into the sinking fund. In addition, the dividends of the state on her stocks in turnpike roads and bridges, and the profits which might accrue from any works of internal improvement were to be added to the fund. 7 The excess of the surplus over $\$ 10,000$ in the state treasury was also to be paid into the sinking fund. The presidents of the three banks were designated as Commissioners of the Sinking Fund. The governor was to act as president of this board.

Throughout the state at this time, there were in

\footnotetext{
5 Ib1d.

6Ib1d., sec. 20.

7.
} 
existence a number of local boards of internal improvement. Some of these were specifically authorized by the legislature in the act which created the Board of Internal Improvement. The local boards were to act under the authority of the Board of Internal Improvement as to the supervision of the construction projects in their own area. This applied primarliy to the turnpike road projects.

The act of 1835 had included the procedure for the letting of contracts by local boards for construction of internal improvements in which the state was to have an interest. This bill stated that the boards were to employ a competent person to examine any contemplated project and report to the board his findings. If his plan for construction, together with estimates of the probable cost, was found to be satisfactory, the board was then to let bids for construction. The bid was to be awarded to the lowest bldder, all other things boing equal. 8 The contract was to be awarded on the first day of public court, after the invitation to bid had been advertised for thirty days at three public places in the county.?

The board was to secure a bond from the undertaker, payable to the board, and conditioned by the falthful performance of the contract. 10 The completed project was to

8General Assembly, Acts of the General Assembly (1834$35)$, c. 837 , sec. 19.

9 Ib1d.

10Ib1d. 
to be examined and approved by two members of the local board before the contractor could be released from his bond. These local board members, or commissioners, were prohiblted from acting as contractors for any projects under their supervision. 11

These provisions for the conduct of business by the local boards were further implemented in 1836, when the legislature directed that the local boards report to the governor on an annual basis. These reports were intended to keep the state officlals informed of the projects undertaken for improvement and the extent of state subscription of stock.

At the first meoting of the Commissioners of the SinkIng Fund at which business was transacted, it was reported that these instructions were not being complied with. 12 The commissioners instructed the secretary-treasurer to make an inquiry of the president of the Board of Internal Improvement to determine the extent of the state interest in projects throughout the state. The president was unable to give the requested information and replied that local boards were not making the required reports. 13 The governor also had no knowledge of the actual progress which had

\section{Ib1d., sec. 30 .}

12Commonwealth of Kentucky. Minutes of the Commissioners of the Sinking Fund, 1836-1844, (In the files of the Kentucky State Arch1ves, Frankfort), December 9, 1836.

13Ibid. 
been made at that time. This was alarming in view of the fact that $\$ 452,650$ had boen spent for all improvements durIng 1835 and 1836. Of this amount, $\$ 309,856$ hed been spent for turnpikes, the detalls of which were unknown to the governor or president of the Board of Internal Improvement. 14

14General Assembly, "Report of the Commissioners on the Expenditure of the Board of Internal Improvement," Legis lative Documents $(1847-48)$, p. 744 . 


\section{CHAPTER V}

\section{THE MAJOR PROJECTS UNDERTAKEN}

The creation of the Board of Internal Improvement and the subsequent legislation represented somewhat of a victory for those supporting river improvements. In the jears prior to 1835, the amount spent for river improvement was only $\$ 33,500$, which was slightly more than $10 \%$ of the amount spent for turnpike roads. 1 This would be greatly changed in the next fow years.

The greatest amounts of state money would st111 be spent for turnpike roads, but would be a much smaller percentage of the money spent for all improvements. This was due mainly to the spending of the large amounts of money necessary for improving the great river systems throughout the state. Improvements on these three systems, the Kentucky, the Green, and Barren, and the Licking, ultimately accounted for almost $40 \%$ of the amount spent for internal Improvements.

Those areas of the state which were touched by one of these rivers, and would be crossed by one of the major turnpikes, were indeed fortunate. A traveler to Bowling

I"Report of the Board of Internal Improvement for 1837," General Assembly, House Journal (1837-38), Append1x, p. 405 . 
Green commented upon the onthusiasm in the latter part of 1836.

Bowling Green is a thriving and handsome town, which has very flattering prospects opening before 1t. A broad and ologant turnpiko is in progress, connecting it with Louisvillo, and another connecting it with Lexington and NashVille; and in addition to this, preparations for slackwater navigation are going on to completion, connecting the waters of Big Barren, which skirts the town, with those of Green River. Through these new channels, produce of varlous kinds can easily find a market, whlle merchandise will be more cheaply imported from distant quarters.2

Th1s enthusiasm was shared by other areas of the state who were benefiting from the great expenditure of money. The appropriations made by the leglslature in 1835 were intended as a significant step toward the achievement of a state transportation network, but their estimation has been unbellevably low. The amounts which were appropriated at that time hardly made more than a start on these huge projects.

W1thout a doubt, the costs of Improving the river systems were greatly inflated. Whother the benefits derived from their improvement fustified the cost is a matter for debate. Cortainly to residents of an area which was onriched by this windfall of state money, the projects were justifiable at any cost. There is no doubt that the improvements were needed, and in most cases navigation of the

2Robert Davidson, An Excursion to the Manmoth Cave (Lexington: A. T. Skiliman and Son, 1840), p. 28. 
streams was made possible by the improvements. Howerer, the total amount of money which was spent for these projects was extremely high for the time and the economic condition of Kentucky.

The Kentucky River Navigation, which was the most widely known of the river projects was to cost $\$ 901,932$. The Green and Barren rivers were to recelve $\$ 859,126$ for improvements, and the Licking River improvements would cost $\$ 372,520.3$ There was some other expenditure for the smaller streams, but these three large systems received practically all of the state money spent for river improvement.

Canals played a minor part in the scheme of internal improvements in Kentucky. None of any importance were built except the Louisville and Portland Canal. This canal was completed in 1831, and was bullt with private and federal funds. The state of Kentucky had shown some interest in the undertaking during its oarly stages, but had falled to make any active contribution.

Whenever canals were proposed, they were for connectIng links between rivers or to bypass rapids. 4 These were merely suggested and none of any importance were constructed. This was primarily due to the abundance of

3General Assembly, "Report of the Comm. on the Expend1tures of the Board of Internal Improvement," Iegislative Documents $(1847-48)$, p. 744 .

4W11liam E. Connelley and E. M. Coulter, H1story of Kentuckr, ed. Charles Kerr, 5 vols. (Chicago: The American Historical Soclety, 1922), II, 724. 
semi-navigable streams, and to the difficulty in construction of canals. Where canals were actually neoded, the topography of the area made construction unfeasible.

The state made a greater effort in the field of railroads than in canals, but it did little in comparis on with county and munlcipal ald. However, the perlod of greatest American rallroad construction did not occur until the fifties, and the state had little interest in any type of improvements at that time. In 1857, the American Railroad Journal declared that, "Of all the States, Kentucky has made the poorest showing in the matter of internal improvements." 5 The largest portion of the state ald went to the Lexington and Ohlo Ra1lroad for assistance in extending the road westward to Loulsville from Frankfort.

Control of the road as far as Frankfort was taken over by the state and placed under the control of the Board of Internal Improvement in 1842.6 This had been necessitated by the dire financial position of the road. For the perlod 1838 to 1841, the railroad had falled to meet its interest payments to the state. ${ }^{7}$ The railroad was sold at public

5Amerlcan Rallroad Journal, XXX, 185, 488, quoted in Carter Goodrich, Goverment Promotion of American Canals and Railroads (New York: Columbia University Press, 1960), p. 153.

${ }^{6}$ General Assembly, Acts of the General Assembly (184142), p. 430 .

7Thomas D. Clark, "The Lexington and Ohio Rallroad-A Ploneer Venture," in The Register of the Kentucky State Historlcal Soclety, XXXI, 94, (January, 1933), p. 12. 
auction January 15, 1842, and was bought by the state of Kentucky for $\$ 178,544$. This amount represented the amount of the principal, plus the amount of the interest past due on the state owned bonds. 8 The road was then leased out for its operation.

At this time, an extension of ten years time was granted for the completion of the road to Loulsville. In all, the state of Kentucky spent slightly more than $\$ 600,000$ for ald to rallroads. This represented a little over $10 \%$ of the total spent for internal improvements.

Faster progress was made in the making of turnpike roads than in rallroad construction. "The activity of private companies in byilding turnpikes and in projecting a great many more was immodiately holghtenod by the inaugaration of state ald through the Board of Internal Improvement." 9 By the end of 1837, subscriptions of individual stockholders in incorporated road companies amounted to the sum of nearly $\$ 2,000,0000^{10}$ It is difficult to ascertain the amount of state subscription at this time due to the fallure of local boards to report their activities to the governor as had been ordered in 1836. However, it can be safely stated that the subscription by the state was well

${ }^{8}$ Ib1d.

9Connelley and Coulter, History of Kentucky, II, 727.

10General Assembly, "Report of the Board of Internal Improvement for 1857," House Journal (1837-38), Append1x, p. 20 . 
over $\$ 1,000,000$

In the report of the Board of Internal Improvement for 1837, the board 1isted 343 miles of macadamized road finishod and 236 miles under construction. ${ }^{11}$ The notwork in the central portion of the state was of the highest quality and was the most widely traveled. This network had as its nuclel Maysville, Lexington, and Loulsville. This system of roads was sald to be equal to that located in any other part of the United States. 12

Another Important turnpike was the road which extended southward from Louisville toward Nashville by way of West Point, Elizabethtow, and Bowling Greon. Thls road, which cost some $\$ 5500$ per mile, was constructed in the fashion of the day, and is typical of the turnpikes being bullt at the time. 13

The foundation of the road was formed by placing rough cobblestones across the road to a depth of eight inches. On top of this, successive layers of pounded stone were added to make a finishing coat four inches thick. The grading on the roads was done with the plow, pick, and shovel, as scrapers were not then in use. The rock was

\section{Ibid.}

12J. Winston Coleman, Stage Coach Days in the Bluegrass (Loulsville: The Standard Press, 1935), p. 234.

13s. G. Boyd, "The Loulsville and Nashville Turnpike," Paper read before the F1ls on Club, Loulspille, November 2, 1925. 
crushed with hammers and the knapping hammer was used to smooth the jagged edges of the base rocks. 14 Ditches were dug on each side to provide for dralnage of the roads. These ditches, when dug, added considerably to the cost of the road as the work amounted to nearly 1200 yards of oxcavation per milo. 15

The quality of the roads varied greatly with each road, but they were generally constructed on the same plan. The differences in quality existed due to some roads being built with little dralnage, and with a very shallow foundation and covering of crushed stone. The better roads were built to a depth of nine or ten inches on the edges, and one to three inches deeper in the center to provide for greater wear and for drainage. 16

The generosity of the legislature did not extend to all sections of the state. The funds for river improvement definitely favored those sections of the state which were fortunate onough to be located near one of the great river systems. The policy of distribution of state funds through the subscription for stock by the state in turnpike road companies definitely favored those sections of the state with greater population and prosperity. The mountain roads,

14Ib1d. The author of this paper stated that the foundation of this road was substantially intact in 1925 , when he had inspected 1t.

15 Ib1d.

16Coleman, Stage Coach Days in the Bluegrass, p. 234. 
which had been noarly comparable to the roads in central Kentucky before 1830, fell further bohind in quality each year. 17 These róads were steoper and more subject to frequent washouts, although the materlals for improvement were often better and more easily obtainable than in other sections of the state. The funds which were necessary to match the state subscriptions were hard to raise and the mountain region as a whole suffered from poor roads. The state assistance for internal improvement was actively courted by businessmen and politicians in all areas of the state for it enriched their own region in two main ways. The main reason given, and the most obvious one, was that improvement of the state's transportation facilities would add greatly to the amount of trade, thus causing the economy of the area to grow. This would benofit the state as a wholo, and would be justification enough for the expenditure of state funds. This did happen and was one valid reason for the state to involve itself in such a massive program of internal improvements.

Travelers, and other writers of the period, were quite vocal in their praise of the improvements being made at the time.

Macadam roads and slackwater navigation, are giving a new impulse to the trade and prosperity of this section of Kentucky; and the valiey of Green River,

17Mary Verhoeff, The Kentucky Mountains ("Filson Club Publications Number 26," Loulsville: John P. Morton and Company, 1911), p. 168. 
with its handsome and thriving tows, is rising every year in political importance, while it attracts the admiration of the traveller. To say nothing of the lucrative tobacco trade, nor of the trade to the south in livestock, the mineral treasures of this region when fully developed, will constitute an inexhaustible source of wealth. 18

Another reason for the activity of businessmen and politicians in attempting to secure state funds for internal improvement was the effect of the money spent for construction upon the local economy. Supplies and equipment had to be bought for the projects and labor was needed for construction. The money spent for these and other needs acted as a terrific stimulant in the areas where the projects were located.

There were also fantastic profits to be made on these projects. Frequently those who made the strongest appeal for state funds contracted to make the improvements. The act which created the Board of Internal Improvement specIfled that local commissioners be prohibited from being contractors of projects under their supervision. This was further implemented by acts of the legislature restricting the authority of the Board of Internal Improvement and the local boards. An act passed February 16, 1838, provided that roads were not to be put under contract without the authority of the Board of Internal Improvement. All roads were to be surveyed before they could be put under contract. 
The act also specifically warned the president and the board members to be aware of, and guard against frauds by contractors. They were instructed to "prevent individual subscriptions from being made, not of a fair and bona fide character, but for the purpose of procuring subscriptions on the part of the state merely with the expectation of becoming road contractors, and not with the intention to pay the amount of their subscription in good falth." 19 As the financial affairs of the time became more strained, the local contractors and their profits would bo examined more closely, and some irregularities would be exposed. For the most part, however, a large amount of the money spent for internal improvements would ultimately go to various contractors as profit.

19General Assembly, Acts of the General Assembly, $1837-38$, c. 256 , sec. 19. 


\section{CHAPTER VI}

\section{PROBLEMS IN FINANCING THE IMPROVEMENTS}

The year 1836 ended well for the advocates of internal Improvements in Kentucky. As late as September, state scrip had sold in New York at a premium. Many projects were in progress, and many more were under contract. While the legislature continued to be extremely generous with appropriations for internal improvements, it retained control over the board. The amount of money which could be borrowed was Iimited, and the provisions for spending state money were specifically stated.

The board was instructed to make an estimate of the money neoded for each jear by June 1, and scrip was to bo issued to cover the amount needed. However, the sum est1mated and borrowed could not exceed the amount authorized by law. ${ }^{I}$ The provisions for turnpike road companies had to be met before the board could subscribe stock, and no money could be spent unless authorized by law and appropriated by the legislature. ${ }^{2}$ The board was further prohibited from putting any locks or dams under contract unless authorized by the legislature.

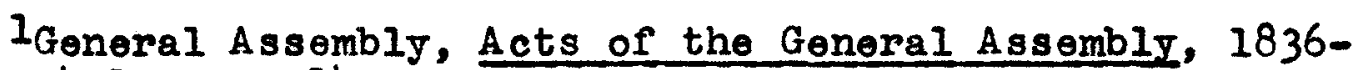
37. c. 471 , sec. 14 .

$$
\text { IIb1d., sec. } 20 .
$$


While it appeared that all was well with the internal improvements program of the state, there were some hints that tho state's financial picture was not as sound as was thought.

The act which established the sinking fund for the state had provided that the excess of the surplus in the state treasury over $\$ 10,000$ be paid into the sinking fund. When the commissioners met in December, 1836, the secretarytreasurer of the fund made an accounting of the funds for which the commissioners were responsible. He indicated that $\$ 62,443$ had been received by the state treasurer to go into the sinking fund. After the disbursements had been made, the treasurer held the amount of $\$ 31,429$, which was to be paid to the fund. 3

The treasurer replied to a demand of the commissioners that he was unable to pay this amount but he could pay approximately $\$ 20,000$ at this time.4 The full amount which was due the sinking fund was not pald unt il January 11, 1837. No explanation was made of where the money had been, or of where the treasurer finally acquired the necessary amount. This incident, though small, indicates the poor way in which the state funds were handled and the possibilities for misuse of public funds.

Kentucky, Minutes of the Commissioners of the Sinking Fund 1836-1844, December 9, 1836.

4 Ib1d. 
The apparent soundness of the state's finances was shown to be somewhat misleading early in 1837. The Board of Internal Improvement, in its report made to the legislature at the end of the year, stated that by April it had become acutely concerned with the problem of maintaining the improvements for the year.

At this time the Board thought it probable that the scrip of the State would not sell, during the heavy commercial embarrassments into which the country has been thrown. The only means provided by law for the prosecution of our Internal Improvement system, were loans from banks and the proceeds from the sale of scrip; but our banks, following the lead of those in other states, suspended specie payments on the 19th and 20th of May, and were not, in this prostration of the credit system of the United States, in a condition to afford loans adequate to our wants; and the fallure of the sale of the State scrip left the Board without the means of discharging existing liablities. These were the painful facts which compelled the Board to come to the determination not to commence any now works over which they had discretion, yntil they could take counsel from the Legislature.5

The extent to which the state had plunged into internal improvements is best illustrated by the fact that although no new projects were started during this year, the expenditure amount to $\$ 866,221.6$ This was the second greatest expenditure for improvements made in any one year and represented only the payments on projects under construction. Had not the panic of 1837 occurred, the

5General Assembly, "Report of Board of Internal Improvement for 1837," House Journal, 1837-38, Append1x, p. 17.

6General Assembly, "Report of the Commissioners on the Expenditures of the Board of Internal Improvement, Legis lative Documents, 1847-48, p. 744 . 
participation of the state in these projects might have reached truly fantastic proportions.

The fallure of the Board of Internal Improvement to undertake any new projects for 1837 caused considerable financial difficulty for contractors throughout the state. The commissioners of the sinking fund reported at their meeting of June 8, 1837, that frequent applications were made to them by various turnpike road companies and other local corporations proposing that the commissioners subscribe for stock or loan money for their ventures. These appeals were rejected on the grounds that the commissioners did not have the authority to subscribe for stock or make such loans. 7

By September, 1837, the Board of Internal Improvement had declded that even the projects under construction could not be continued. The board appealed to the commissioners of the sinking fund for additional sales of state scrip to prevent the halting of work already under contract. Due to the "consequences of the great depression," the attempts to sell additional scrip failed. The commissioners then authorized the purchase of $\$ 200,000$ in Kentucky Internal Improvement Bonds. 8

The financial crisis was of such a severe nature that

7 Kentucky, Minutes of the Commissioners of the sinking Fund, 1836-184h, June 8, 1837 .

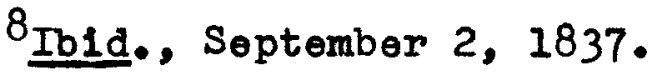


the state of Kentucky would have not been able to meet her obligations without the division of the surplus revenue of the United States. For the year 1837, the sinking fund recelved the sum of $\$ 1,023,287$. Of this amount, $\$ 850,159$ was recelved from the national government. 9

This sum of $\$ 850,000$ was paid into the sinking fund for the purpose of establishing a school fund. Seoing the need for additional funds to promote the interest of the state in internal improvements, the commissioners decided to invest this sum in internal improvement bonds. They explained their actions in the report to the legislature for the year.

To invest it in foreign stock was thought to be unadvisable; to have done so, the commissioners would have been driven to the necessity of withdrawing Irom Kentucky the entire sum, thus lessening the circulating medium of the state, and thereby depriving not only the state, but every individual citizen of the benefits resulting from the retention and distribution of so large an amount of money among them. Had $\$ 850,000$ at the present crisis of our monetary affairs been withdrawn from the state, and invested in other sections of the United States, the present derangement of our currency would have greatly augumented, and the commerce and agriculture, the manufacturing and mechanical arts throughout Kentucky, would have recelved an additional shock in all their varied ramifications. Had this money been invested in internal improvement bonds of other states.... they would have enjoyed its benefit while Kentucky was suffering most disasterously under 1ts withdrawal-her system of internal improvements entirely arrested, and her credit seriousiy offected if not prostrated by her consequent inability to fulfil her contracts.10

9Ib1d., February 26, 1838.

10 Ib1d. 
While continuing to appropriate money for the completion of profects already undertaken, the legislature approached the problem of internal improvements rather cautiously in the session which began in December, 1837. Even before the annual reports of the board and the sinking fund were given, it was apparent that the state was in acute financial embarrassment. The suspension of payment of specie by the b anks had continued, and the f1scal pleture of the state was indeod bleak. Early in the session, a member of the House of Representatives had attempted to introduce a bill to abolish the board but was rebuffed in his effort. 11

The responsibility for the further involvement of the state in works of internal improvement rests clearly with the leglslature. The Board of Internal Improvement had declined to approve any new projects unt1l the wishes of the leglslature had been determined. The commissioners of the sinkinf fund warned that "to progress with our own system of Internal Improvements, it is essentially necessary to effect sales of our scrip. To create a demand in the market for our bonds, it is indispensable that the means of meeting the interest, and their certain and final redemption should be provided." 12

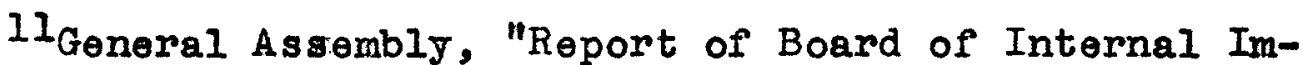
provement for 1837," House Journal, 1837-38, Appendix, p. 56.

12Kentucky, Minutes of the Commissioners of the SinkFund, 1836-44, Fobruary 26, 1838.

54 
The commissioners further stated that of all the prescribed sources of possible revenue, the only certain source was the bonus on the capital stock of the Bank of Kentucky, the Northern Bank of Kentucky, and the Kentucky Bank of Loulsville.13 They called for immediate action to provide further sources of revenue for the sinking fund. While 1t still was not fully apparent that the system of Internal Improvements was swiftly leading the state toward financial ruin, there was enough evidence to cause the legislature to examine the long range effect of the program. This was not done, and the sentiment for internal Improvements reached new highs after the crisis of 1837 had passed. The projects alroady under construction were a drain on the finances of the state, even if no now projects had been undertaken. The financial crisis of 1837 had made little impact on the advocates of internal improvements.

13 Ib1d. 


\section{CHAPTER VII}

THE END OF INTERNAL IMPROVEMENTS

With the financlal crisis of 1837 past, the legislature resumed the appropriations for works of improvement with new vigor. This necessitated the sale of additional state bonds, and on July 1, 1838, the largest single issue of the period was made. This issue, which was in the amount of $\$ 1,250,000$, was needed to pay the costs of construction which were almost $\$ 1,000,000$ for the jear. ${ }^{1}$ This marked the maximum offort made by the state for internal Improvement.

One of the factors which had led to the financlal difficulty of the state was the lack of tolls collected on behalf of the state. Supporters of the works of improvement had argued that the tolls collected on the improved projects would pay for the costs of construction, and in many cases, actually represent a profitable investment for the state. It soon became evident that the state's portion of the tolls was far below that which had been expected. As previously mentioned, the cormlssioners of the sinking fund had been concerned with the fallure of local boards

IGeneral Assembly, "Report of the Commissloners of the Sinking Fund for 1850," Leglslative Documents, 1850-51, p. 557. 
to report the holdings of the state in turnpike road companies. The requests made to the local boards had gone largely unanswered, and through 1838, the state was recelving very little money as its share of tolls collected.

In compiling their report to the legislature for 1838 , the commissioners wished to call attention to this problem. They felt that the legislature should be aware of this, for It actualiy constituted a shortage of state funds. At this time, there were many roads in operation and the state's share of the tolls should have been substantial. The commissioners made the following statement in their report.

It is scarcely probable, with the great extent of turnpike roads and the bridges already constructed and in successful operation, in which the state is interested, that there should not be some revenues collected-same profit recelved-beyond the expense of collection and repairs; and yet, from very fow, Indeed from but two of these roads, has one cent beon recelved during the present year, one of wh 1ch being under the exclusive control of the state. There is olther some radical defect in the construction of these roads, or a disregard on the part of the managers thereof of the existing laws upon the subject; other states derlve a certain revenue from those sources, where the rates of toll are not higher than in the state of Kentucky.?

This report of the commissioners to the legislature had little effect as only five companies returned tolls to the state for 1839, and they amounted to less than $\$ 5,000$.

2Minutes of the Commissioners of the Sinking Fund, 1836-44, March 9, 1839. In add1tion to the Muldrows Hill and the Maysville, Washington, Par1s, and Lexington Turnpike companies mentioned here, the Shelby County and the Springfield and Bardstown turnpikes had ylelded dividends to the state prior to 1838. These were the only companies to submit tolls to the state for the period 1835-1838. 
of this amount, $\$ 2,798$ came from the Maysville, Washingtion, Paris, and Lexington Turnpike Road Company. 3

By early 1840, the financial situation was becoming desperate again in Kentucky. The state debt was now over $\$ 2,000,000$ and it had become quite a problem to make the interest payments. In order to finish work already undertaken, the legislature provided that contractors could be paid in state bonds if they would accept them. This only applied to work already completed, but in order to be more attractive to the contractors, the commissioners of the sinking fund and the Board of Internal Improvement agreed to give bonds for "work to be done as estimates may be presented to the Board." 4

The proceeds from the bonds which the state was able to sell, were distributed to the contractors on a pro rata basis. The logislature stipulated that the money from the sale of new bonds might not be used to pay the interest on the debt already owed.

Faced with a mounting state debt, and with many expensive projects already undertaken, the legislature directed that no new works be undertaken for the jear 1841 . The profects which were in the process of being completed

3Ib1d., December 13, 1839.

4 Ib1d., March 25, 1841. 
would cost over $\$ 1,000,000$ for 1841 and $1842 .^{5}$ However, these years would be the last in which the state made such expenditures for internal improvements. The amount spent for 1843 was $\$ 98,170$, and represented quite a reduction from the $\$ 462,604$ spent for $1842 .^{6}$

The completion of the major projects, together with the prohibition of now projects accounts for the drastic decrease in expenditures. This was fortunate for the state, because the debt had risen to over $\$ 4,000,000$ by mid 1842, and the financial resources of the state were strained to utmost. From 1843 through 1847, the state spent $\$ 265,000$ to complete various projects already nearing completion. 7 In 1846 and 1847, commissioners were appointed by the legislature to settle the accounts and audit the records of the Board of Internal Improvements.

Although the board remalned in existence unt1l the 1860 's, its activitios were limited to collecting tolls and supervising repairs on the facilities under its control. Even though the powers and the importance of the board had decreased sharply with the completion of the major projects, many poople desired to protect the state in some way from any return to state ald for public improvements. This was accomplished in the constitution of 1850 .

5 General Assembly, "Report of the Cormissioners on the Expenditures of the Board of Internal Improvement," Legislet1ve Documents $1847-48$, p. 744 .

${ }^{6}$ Ibid.

7 Ibid. 
The convention which met in 1849 to consider revising the constitution debated the issue of internal improvementa and decided its fate by placing a debt limitation on the state which read: "The general assembly may contract debts to meet casual deficits or fallures in the revenue; but such debts, direct or contingent, singly or in the aggregate, shall not any any time exceod five hundred thousand dollars; and the moneys arlsing from loans creating such debts shall be applied to the purposes for which they were obtalned, or to repay such debts." 8

To implement this act and give further assurances, the constitution provided that, "The credit of this cammonwealth shall never be given or loaned in ald of any person, association, municipality, or corporation." 9 The constitution also provided that the president of the Board of Internal Improvement was to be elected by the voters of the state for a four year period. The general assembly was given the power to abolish the board or the offlce of the president at its discretion. 10

The debates over internal improvements at the convention were quite heated and contered around the provision to Iimit the state debt to $\$ 500,0000^{11}$ some of the

8 Kentucky, Constitution 1850, (Frankfort: William Tanner and John W. FInnell, 1850), Art. 2, sec. 35.

9 Ibid., Art. 2, sec. 33.

10 Ib1d., Art. 8, sec. 23.

11 Convention Debates, p. 757 . 
delegates wishes to make the limit $\$ 50,000$, but it was pointed out that this would not be sufficlent to rebuild the state capitol in the event it might be destroyed. 12 Despite the disagreement over the celling on the state debt in the future, it was generally agroed that the state had undertaken debts greater than her ability to r epay. 


\section{CHAPTER VIII}

EVALUATION OF THE BOARD OF INTERNAL IMPROVEMENT

In order to make a fair evaluation of the Board of Internal Improvement, certain factors must be considered. This study, which attempts to examine the workings of the board, is actually a broad examination of the period of Internal improvements in Kentucky. The papers of the board are not available at this time and a detalled examination of the board itself is difflcult without them. The reports of the board to the legislature are lengthy, but they give Iittle information about the board 1tself. The conclusions drawn are therefore based on the materials used and are subject to dispute.

There are some conclusions which may be immediately draw and are generally agreed upon. The improvements which were made definitely benefited the state and from this standpoint can be considered successful. The fac1l1ties for transportation before the inaugaration of state ald were Inadequate, and the works did much to improve travel and transportation. There was by no means an effective system of roads throughout the state, but the major clties were connected by roads of fairly good quality. The local roads did not benefit a great deal from the state a1d 
and remained in poor condition for a great many years.

The Improvements made on the Kentucky and the Green

and Barren Rivers were successful in aiding navigation and in promoting trade in the areas through which they flowed. The work on the locks and dams were often of poor quality, but their size was sufficlent for the boats of the day. Much of the construction done on the locks and dams on the Kentucky River was later replaced when the state relinquished control to the national government. 1

The work on the Licking River was suspended in 1843 and the improvements already made constituted a total loss. The Board of Internal Improvement met in Covington, in accordance with an act of the legislature of March 11, 1843, to settle accounts with the contractors. 2 It was estimated that $\$ 40,000$ more would have completed the first five locks on the river.

As previously stated, the state spent little money for the construction of canals and railroads. The money spent for canals was negligible. The total spent on the construction of the Lexington and Ohio Railroad was less than $10 \%$ of the total spent for all improvements, and came to

IAlfred Pirtle, "Some Early Englneers and Architects in Kentucky," The Reglster of the Kentucky State Historical Soclety, Vol. I2, No. 60 (September, 1914), p. 29.

2General Assembly, "Special Report of the Board of Internal Improvement," Iegls lative Documents 1842-43, p. 45. 
$\$ 322,553.3$ This was the total amount spent for rallroads, except for $\$ 1,903$ for the Green River Rallroad. 4

The financial troubles which beset the state were caused by a number of things. There is no doubt but that the state over-extended 1ts credit and brought on the financial crises which forced the ond of state financing of internal improvements. This was primarily due to the inability of the state to recover the amounts in tolls which had been anticipated. The legislature fully expected the projects to pay for themselves and to be a continuing source of income for the state. This proved to be far from correct, and Instead of paying huge dividends, many of the works had to have additional funds granted for repalrs and expenses of maintenance.

The people were told in both branches of the legislature that all the money they were borrowing for those internal improvements would be repald by the profits of those works, and that the people would never be called upon to pay a dollar of it. They were told that these improvements would jiold a divident sufficlent to pay not only the accruing interest, but the principal of the debt, and also ald in lessening the taxes of the poople. Well, the people, by sad experience, have found out that these gentiemen were m1staken on the subject. 5

One reason for the fallure of the turnpike roads to produce the anticlpated tolls was the difficulty in their

3onvention Debates, p. 762.

4Ib1d.

5 Ibid. 
collection. In many instances, small roads were built around the toll gates and travelers, particularly the local residents, used the roads freely without paying any tolls whatever. The state's portion of the tolls which were collected never reached the state treasury or the sinking fund to any great degree. Whether the roads actually made any profits is hard to determine, but there was no shortage of persons who were attempting to gain the state assistance for their construction. The difficulties in communication made it almost impossible for the Board of Internal Improvement or the commissioners of the sinking fund to effectively keep up with the various companies throughout the state.

Due to the small budget of the state, it was virtually impossible to make the necessary interest payments and eventually repay the loans without substantial profits from the projects. The total recelpts of the state from october 11, 1833, to October 10, 1834, had been only $\$ 162,008.68 .6$ The expected revenue for 1835 was estimated at $\$ 171,446.26$, and would be insufficient to pay the estimated expenditure for the jear. 7 By 1843, the receipts had risen to $\$ 374,216.14$, with $\$ 108,519$ boing paid into the sinking

6General Assembly, "Report of the Treasurer," House Journal 1834-35, pp. 60-61.

7General Assembly, "Report of the Auditor," House Journal 1834-35, p. 54. 
fund. ${ }^{8}$ For 1844 , the estimate of revenue was $\$ 272,248$, with approximately $\$ 90,000$ to be paid into the sinking fund. 9 By this time, the interest on the state debt amounted to over $\$ 200,000$ a year which was almost as much as the total expected revenue for the state. The situation would have been even more critical if the state had not invested the $\$ 850,000$ of the school fund in internal Improvement bonds in 1837, and would ultimately cancel the bonds and wipe out the school fund. 10

The state had no effective system of control over its finances, whother in the outlying areas or in Frankfort. The commissioners continualiy had trouble collecting the surplus in the state treasury which was to be pald into the sinking fund. During the financial crisis of 1837, the logislature had passed a law calling for the profits arising from the penitentiary to be paid into the sinking fund. This was not done, and a sult was instituted against the former keeper of the penitentiary for funds allegedly misused. 11

This provision was to lead to constant disputes botween the commissioners and the various keepers of the

8 General Assembly, "Report of the Auditor," Legislative Documents 1843-44, p. 6 .

9 Ib1d., p. 18.

${ }^{10}$ Convention Debates, p. 756.

1lKentucky, Minutes of the Commissioners of the Sinking Fund 1836-44, December 14, 1837. 
penitentiary. The commissioners had great diffculty in collecting the money due the sinking fund. The amounts were considerably more than might be expected, for the keeper was called upon to account for bullding supplies allegedly purchased which amounted to almost $\$ 100,000.12$

One of the weaknesses of the Board of Internal Improvement resulted from the fallure of the original act to give the board full power of cholce in investing in turnpike road companies. One of the delegates to the convention for the revision of the constitution commented on this fallure of the legislature to protect the interests of the state adequately.

In the organization, the Board of Internal Improvement had no discretion in the application of public money. It was made imperative on the board that when the stock to be taken by individuals in any road company was subscribed, the state was bound to take her share of the stock. This produced misapplication and some projects were undertaken which we greatly regret. 13

There were cases where individuals made subscriptions of stock for the purposes of obtaining the state funds without any plans to construct the designated road. While these cases are difficult to discover, it is apparent that such schomes were taking place bocause the legislature specifically warned against them. 14 The commissioners

12 Ib1d.

13Convention Debates, p. 771.

14General Assemb1y, Acts of the General Assembly, $1837-38$, c. 256 , sec. 19. 
whlch were appointed in 1846 and 1847 to settle and audit the accounts of the board were to examine to see if payments had been made without authority.

There were also cases of fraud in the sale of the state bonds, and the payment of interest on them. The commissioners of the sinking fund passed a resolution in 1840, declaring that no payment of semi-annual interest be made unt1l the appropriate coupons had been surrendered, or a recelpt from the person to be pald was recelved. 15 After this date, the commissioners refused to pay several claims for Interest where the coupons were sald to have been lost or stolen. It is therefore probably safe to assume that some unfust claims had been pald prior to the passage of this resolution.

Another case of fraud occurred when the commissioners purchased stock of the Bank of Kentucky which proved to be counterfeit.

The recent development of the fraud cormittee by the agent of the Bank of Kentucky at Philadelphia, by the 1ssue of spurious shares of bank stock as In the opinion of the board, made it necessary for this board to take steps to investigate the purchases of the stock of said bank heretofore made by the board for the sinking fund and the Board of Education. 16

After investigation of the Schuylkill Bank in Philadelphia, whlch had been the agent for the Bank of Kentucky,

15 Kentucky, Minutes of the Commissioners of the Sinking Fund, 1836-44, June 11, 1840.

${ }^{16}$ Ib1d., January 1, 1840. 
the commissioners decided to institute a suit to recover the funds lost through the fraud. On August 23, 1841 they passed a resolution to authorize the sult to be piled.

Resolved, that the chalrman of this board be authorized to institute sult or sults to rocover indemnity for the stock held by this board purporting to be stock of the Bank of Kentucky; but denominated by said bank as spurious and emenating (sic) from the Schuylkill Bank as transfer agent for the Bank of Kentucky in Philadolphia, and that sald chairman employ the services of such legal advisors and attorneys in the case as he may deem necessary. 17

These cases illustrate the fact that the state was victimized by unscrupulous individuals, both inside and outside of the state. While the amount of these thefts and frauds cannot be determined, it must be stated that they undoubtedly amounted to an enormous sum. The commissioners of the sinking fund were unable to recover the full sum due the state in several of the cases where sult was actualiy brought against persons accused of misapplication of funds. If there is to be any fault or guilt assessed, it must be directed to the legislature. The legislature had control over the Board of Internal Improvement at all times, and could have ended any project or all of the works by refusing to approprlate funds and authorize loans. This was not done, and the program grew to such extremes that the state was burdened by a debt of $\$ 4,497,637$ at the end of

17 Ibid., August 23, 1841. 
1850.18 The total cost of the improvements to the state had been $\$ 5,344,764$. 19

The legislature was kept informed of the activitios of the board and of the commissioners of the sinking fund, and knew the financial position of the state. In times of financial difficulty, the board refrained from acting until the legislature had been consulted. It then based its actions on the directions of legislature.

The members of the legislature were aware of the financial burden being imposed upon the state, but continued to vote the necessary appropriations, and must bear the full responsibility for the consequences. James Guthrie, who professed to be a supporter of internal improvements, summarized the position which the legislature had taken when the financial picture required positive action. The change of times-the bursting of the bubblebrought a period to the labors of Kentucky upon the system of internal improvements. And, although we did not sell our bonds below par, to meet the balances against us, we gave them to the contractors at par, in payment of what was due to them, when we knew they would have to sell them at a discount; and in many instances they did sell them at a discount of from ten to fifteen percent. 20

Although internal improvements constituted one of the most importent activities of the government for this perlod,

18General Assembly, "Report of Commissioners of the Sinking Fund for 1850," Legls lative Documents, 1850-51, p. 557 .

19Ib1d. 1847-48, p. 744 .

${ }^{20}$ Convention Debates, p. 760 . 
It never became a major political issue. It cannot be said that the Whigs in Kentucky were the party of internal improvements and the Democrats were the opposition. The Whigs did favor improvements generally, but the opposition was due more to location than to party. The Whigs made some political capital when the work was proceoding quickIy, and the state was in good financial condition. The people were in favor of internal improvements and this was known by the legislators.

The men who were the members of the legislature at that time, instituted and carried out that sjstem of internal improvements, did it with the sanction of their constituents. From year to year, they returned to their constituents, who had a full knowledge of what they had done; and these men were again and again elected, for the purpose, and with the view, of fully carrying out that system.21

While the Whigs benefited from the success of the movement, the Democrats had their turn when difficulties began to appear.

The Whigs had made internal improvements their chlef concern and while enthuslasm ran high for these works, they enjoyed a valuable political asset, but when the day of turnpikes and rivers was waning, it was easy for the Democrats to point to the large public debt, incurred in these undertakings, which had not fulfilled the glowing prophesies of a decade and a half ago.22

The period of internal improvements in Kentucky was brief, but it made a lasting impact upon the state. The

\footnotetext{
21 Convention Debates, p. 758. p. 729.

22Connelley and Coulter, History of Kentucky, Vol. II,
} 
value of the improvements to the state was incalculable. Certainly facilities for transportation and travel were superior to those of 1830. The costs of the improvements seem fantastic and unreasonable when the state's ability to repay was considered. However, to those who lived in the time and experienced the hardships of travel, the improrements surely seemed justifled at any cost. 


\section{APPENDIX}

\section{PABLE I}

STATE EXPENDITURE FOR INTERNAL IMPROVEMENTS TO $1847^{\mathrm{a}}$

\section{Year Expenditure}

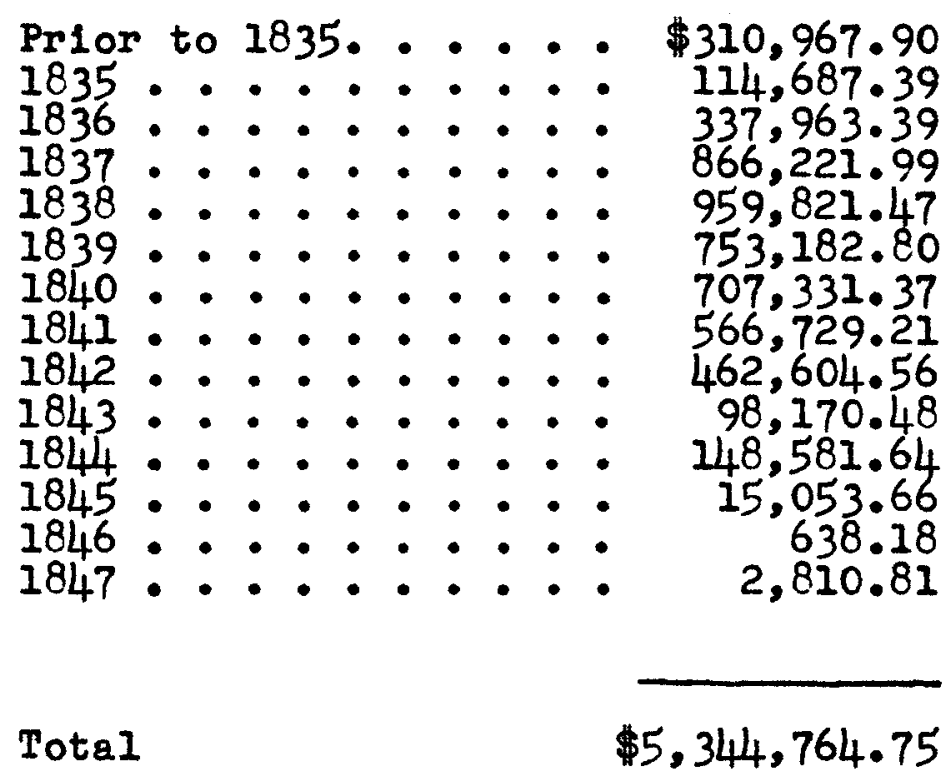

ageneral Assembly, "Report of the Commissioners on the Expenditures of the Board of Internal Improvement," Legis lative Documents, 1847-48, p. 744 . 
TABLE II

STATE EXPENDITURE FOR

TURNPIKE ROADS TO $1850^{a}$

Turnpike

Road
Iength of Finished Amount Paid Road (In miles) by the State

Maysville, Washington,

Paris and Lexington 64

Richmond and Lexington 26

$\$ 213,200.00$

Winchester and Lexington

Laxington to Covington

18
75.383 .00

Frankfort, Loxington and

\section{Versailles}

73
$45,100.00$

Frankfort to Georgetowm 27

Maysville and Mt. Sterling

Maysville and Bracken

Lexington to Danvilie and

Lancester

17

$78,122.00$

Hardinsville to Crab Orchard

Frankfort to the Jefferson

County Line

22
$58,725.00$

Louisville via Bardstown to

the Tennessee Line

12
$88,072.59$

$25,948.00$

Loulsville via Elizabethtown

to the Tennessee Iine

42

$151,382.00$

65

$183,113.00$

Logan, Todd, and Christian

Muldrow Hill Road and Bridgo

Springfield and Bardstown 32

$65,000.00$

Versallles and Anderson County

Lexington, Harrodsburg and

Perryville

Owingsville and $\mathrm{BIg}$ Sandy

Totals

775

103

$500,210.57$

108

$441,383.25$

$17 \quad 149,428.91$

$5 \quad 55,145.46$

18

$65,190.60$

$6 \quad 20,000.00$

aGeneral Assembly, "Report of the Board of Internal Improvement for 1849," Iegis lat1ve Documents, 1849-50, p. 531 . 


\section{TABLE III}

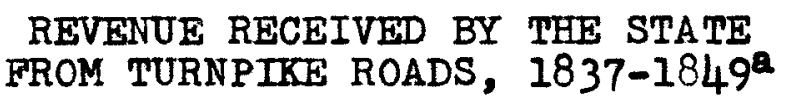

Year Amount Recelved

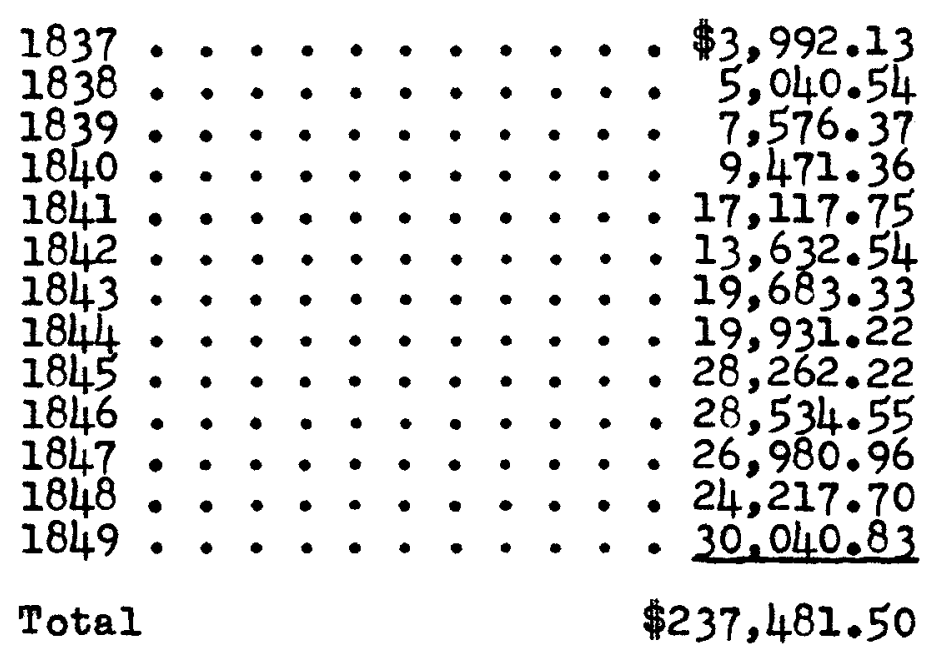

a General Assembly, "Report of the Board of Internal Improvement for 1849," Legislative Documents, 1849-50, p. 531. 
TABLE IV

STATE DEBT ARISING FROM THE SALE OF

BONDS FOR INTERNAL IMPROVEMENTS ${ }^{a}$

Date Issued Amount Issued Balance Outstanding

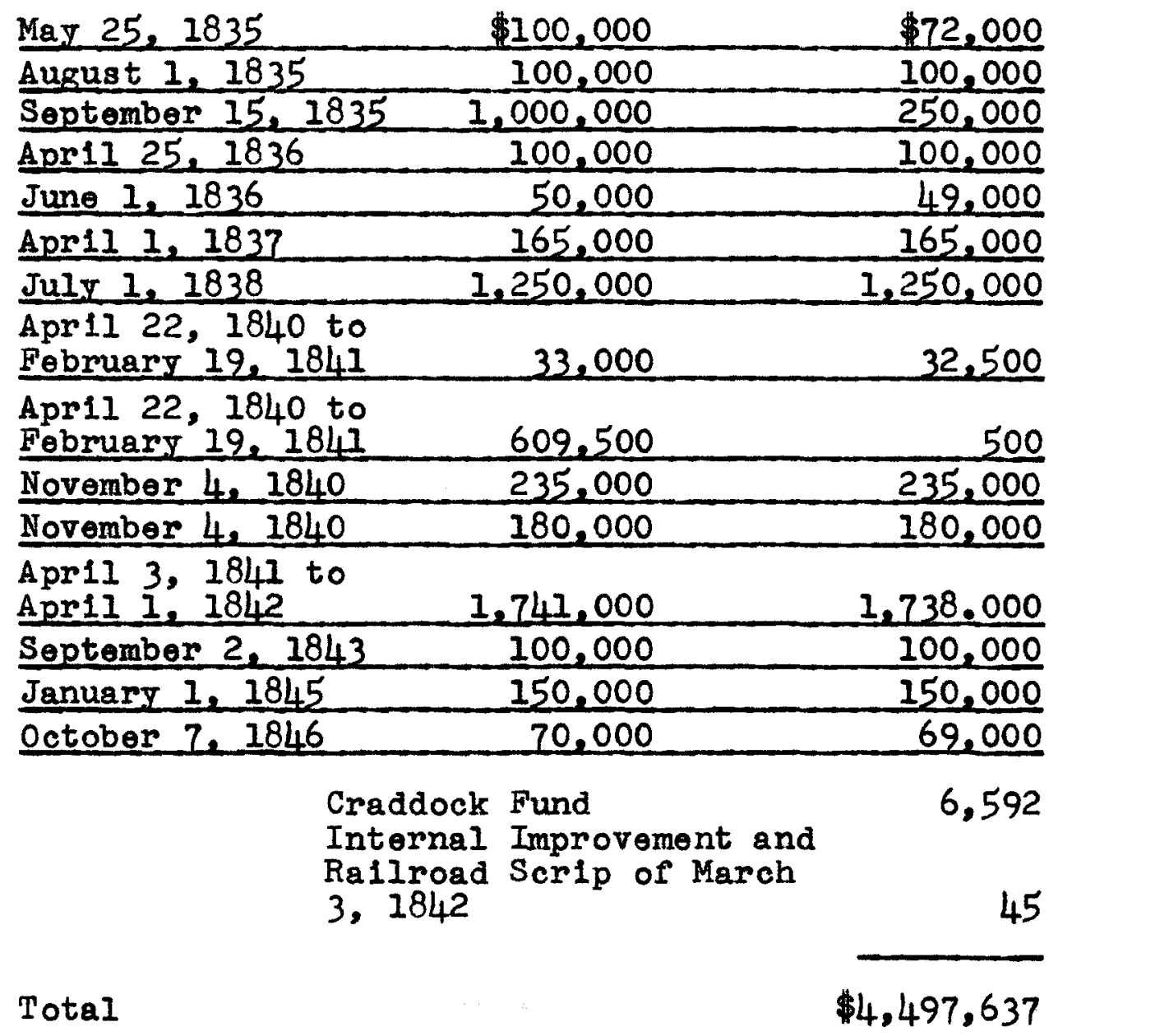

aGeneral Assembly, "Report of the Commissioners of the Sinking Fund for 1850," Legislative Documents, 1850-51, pp. 557-558. 


\section{BIBLIOGRAPHY}

\section{Public Documents}

Commonwealth of Kentucky. Constitution, 1850. Frankfort, Kentucky: William Tanner and John W. Finnell, 1850.

Commonwealth of Kentucky. Report of the Debates and Proceodings of the Convention for the Revision of the Constitution of the State of Kentucky. Frankfort, Kentucky: A. G. Hodges and Company, 1849.

General As sembly of Kentucky. Acts of the General Assembly of Kentucky. Frankfort, Kentucky: Various printers far the various years, 1834-1850.

General Assembly of Kentucky. Journal of the House of Representatives. Frankfort, Kentucky: Various printers for the varlous years, $1837-1847$.

Generel Assembly of Kentucky. Legislative Documenta. Frankfort, Kentucky: Various printers for the various years, 1847-1851.

General Assembly of Kentucky. Journal of the Senate. Frankfort, Kentucky: Varlous printers for the various years, $1835-1841$.

Commonwealth of Virginla. Statutes At Large. W1lliam Waller Henlg. Richmond: George Cochran, Vols. X, XII, $1779-1785$.

\section{Books}

Ambler, Charles Henry, A History of Transportation in the Ohlo Valler. Glendale, Californla: The Arthur H. Clark Company, 1932.

Clark, Thomas D. A History of Kentucky. New York: Prentice-Hall, Inc., 1937.

Coleman, J. Winston. Stage Coach Days in the Bluegrass. Louisville: The Standard Press, 1935.

Collins, Lewis. History of Kentucky. 2 vols. Revised by Richard H. Collins. Loulsville: John P. Morton and Company, 1924. 
Connelley, W1lliam E., and Coulter, E.M. History of Kentuckr. 5 vols. Edited by Charles Kerr. Chicago: The American Historical Association, 1922.

Davidson, Robert. An Excursion to the Manmoth Cave. Lexington: A. T. Sk111man and Son, 1840 .

DeBow, J. D. B. The Industrial Resources, Etce, of the Southern and Western States. 3 vols. New Orleans: Published at the office of DeBow's Review, 1853.

Goodrich, Carter. Government Promotion of American Canals and Railroads, 1800-1890. New York: Columb 1a University Press, 1960.

Hall, Frederick. Lotters From the East and From the West. Washington: F. Taylor and WIIIIam Morrison, 1840.

Johnson, E. Polk. A History of Kentucky and Kentuckians. 2 vols. Chicago: The Lewis Publishing Company, I9I2.

Kincald, Robert $L$. The Wilderness Road. Indianapolis: The Bobbs-Merri11 Company, 1947.

Sm1th, Z. F. The H1story of Kentuckr. Loulsville: Courler Journal Job Printing Company, 1886.

Swem, Earl Gregg (ed.). Letters on the Cond1tion of Kentucky in 1825. New York: Charles F. Heartman, 1916.

Tanner, H. S. The American Traveller; or Guide Through the United States. Philadelphia: Published by the Author, 1840.

Taylor, George Rogers. The Transportation Revolution, 1815-1860. Vol: IV of The Economic History of the United States. Ed1ted by Henry David, et al. New York: Rinehart and Company, 1951.

Verhoeff, Mary. The Kentucky Mountains. (Number 26 of The Filson Club Publications.) Loulsville: John P. Morton and Company, 1911.

Verhoeff, Mary. The Kentucky River Navigation. (Number 28 of The Filson Ciub Pubilcations.) Louisvilie: John P. Morton and Company, 1917. 


\section{Articles and Porlodicals}

Allen, Turner W. "The Turnpike System in Kentucky: A Review of State Road Pollcy in the Nineteenth Century," The Filson Club Quarterly, Vol. 28, No. 3, (July, 1954), pp. 239-260.

Clark, Thomas D. "The Lexington and Ohio Ra1lroad-A Pfoneer Venture," The Register of the Kentucky State Historical Soclety, Vol. 31, No. 94 (January, 1933), pp. 9-28.

Cotterill, Robert S. "James Guthrie-Kentuckian, 17921869," The Register of the Kentucky State Historical Soclety, Vol. 20, No. 60 (September, 1922), pp.

Frankfort Commonwoalth. 1834-35.

Louisville Daily Journal. 1847-49.

Loulsville Examiner. 1849-50.

Louisville Weokly Courier. 1849-50.

P1rtle, Alfred, "Some Early Engineers and Architects in Kentucky," The Register of the Kentucky State Historical Society, Vol. I2, No. 36 (September, 1914), pp. 37-53.

The Whig Almanac. New York: Greeley and McElrath, 1838-50.

\section{Unpublished Material}

Boyd, S. G. "Louisville and Nashville Turnplke." Paper read before the Filson Club, November 2, 1925.

Commonwealth of Kentucky. Minutes of the Commissioners of the Sinking Fund. 1836-44. Kentucky State Archives, Frankfort, Kentucky. 